MICHA

Państwowa Wyższa Szkoła Filmowa, Telewizyjna i Teatralna im. Leona Schillera

\title{
Refleksja z katedry
}

Bez mała 70-latek, który w wieku 6o lat wrócił do swej Alma Mater, aby nauczać filmu dokumentalnego studentów wydziału operatorskiego. Młodość i wiek męski poświęciłem fotografowaniu filmów dokumentalnych. Przez pół dekady na przełomie lat 8o. i 9o. byłem operatorem newsów telewizyjnych w poważnej amerykańskiej sieci telewizyjnej. Najpierw w Polsce, a potem w Rosji. To była bardzo ważna cezura w moim życiu. Po powrocie do kraju podjąłem samodzielną działalność reżyserską i producencką.

W tamtym momencie musiałem na serio zastanowić się, czym jest film dokumentalny, kto finansuje produkcję, kto ogląda? Polska Ludowa - socjalistyczne, opiekuńcze państwo, ale także państwo trzymane w uścisku cenzury i centralnego sterowania - stało się historią. Doświadczenie operatorskie pozostało we mnie, ale umiejętności reżysersko-producenckie musiałem zdobywać od zera. Wówczas na świecie zaczynało dominować myślenie o filmie dokumentalnym jako o historii interesująco i nowatorsko opowiedzianej. Ono szybko przyjmowało się również w polskiej telewizji. W podtekście chodziło o to, aby widza przykuć do krzesła przed telewizorem - a przy okazji skłonić go do obejrzenia reklam. Zrozumiałem działanie tego mechanizmu, tego sprzężenia zwrotnego, realizując film Wojny innych ludzi (1996), który zamknął i podsumował okres mojej pracy dla amerykańskiej sieci ABC News. W polskiej telewizji „słusznie minionego okresu” naruszenie integralności dzieła filmowego poprzez wstawienie w środek „obcego ciała” - reklamy, było nie do pomyślenia. Takie rzeczy działy się na dekadenckim Zachodzie, w zdegenerowanej Ameryce. Oczywiście w lekko krzywym zwierciadle przedstawiam mój stan umysłu z czasów młodości. Po przewrocie roku 1989, po zniknięciu państwowego monopolu na informację, w nowo powstałych prywatnych telewizjach zagościła reklama. Kursował wtedy bon mot przypisywany anonimowemu menedżerowi telewizyjnemu, że właściwie nie interesuje go, co się puszcza między blokami reklamowymi, gdyż z jego punktu widzenia to był kłopotliwy dodatek.

O nauczaniu filmu dokumentalnego na wydziale operatorskim. Pięćdziesiąt lat temu, gdy byłem studentem, nie istniał jeszcze taki przedmiot - choć przecież fotografowaliśmy dokumenty reżyserskie i było to traktowane przez wszystkich bardzo poważnie. Dzisiaj jednym $\mathrm{z}$ bardzo istotnych komponentów nauczania młodych operatorów

Images

vol. XVII/no. 26

Poznań 2015

ISSN 1731-45OX
Kto pisze?

O czym piszę? 
na naszym wydziale jest ich samodzielność realizatorska. W zakresie dramaturgii (pisanie własnych scenariuszy do ćwiczeń), w zakresie reżyserowania oraz kształtowania scenografii. Tej samej zasadzie ogólnej podlega nauczanie filmu dokumentalnego. „Będziecie lepszymi operatorami w zawodowym życiu - mówię studentom na pierwszym spotkaniu - jeśli sami stworzycie film dokumentalny, od A do Z”. Wiem z własnego doświadczenia, że dopiero konieczność poklejenia ze sobą ujęć, konieczność ułożenia logicznego ciągu obrazów uzmysławia własne niedoróbki, niechlujstwo i lenistwo. Operator dostarcza reżyserowi i montażyście materiał, a po długim czasie widzi elegancki gotowy film, który musi finalnie „dopracować” (dawniej nadzorowaliśmy wykonanie kopii wzorcowej). Nie słyszał tych wszystkich „jobów”, które padały pod jego adresem w montażowni za spartolone ujęcia, brudy w kadrze, za brak planu ogólnego albo kontrplanu, za chwiejny obraz. Tego trzeba doświadczyć na własnej skórze. A droga do tego wiedzie przez montażownię.

Realizacja własnego filmu - od znalezienia tematu i pomysłu na realizację poprzez zdjęcia, montaż i udźwiękowienie - to najlepsze, co Szkoła im daje jako przyszłym operatorom. Oni jeszcze tego nie rozumieją. Ta prawda odsłoni się przed nimi dopiero za parę lat. Szkolny trening samodzielnego myślenia, praktyka w twórczym działaniu ku opowiedzeniu logicznej historii na ekranie jest nieoceniona dla przyszłych operatorów.

Skoro mówię „A”, muszę także powiedzieć „B”. Kiedy stawiamy przed studentami zadanie realizacji dwóch filmów dokumentalnych na kolejnych latach studiów, nie tworzymy osobnego podgatunku dokumentalnego filmu operatorskiego. Bo niby jaki miałby być? Gorszy? Oceniany z taryfą ulgową? Bez słowa mówionego? Studenci mają realizować normalne filmy dokumentalne w takim gatunku, jaki sobie wybiorą, dowolnymi środkami - a moje główne zadanie na etapie poszukiwania przez nich tematu sprowadza się do trzymania ich blisko ziemi i pilnowania, żeby „mierzyli zamiary na siły i środki”, a nie odwrotnie.

Proces codziennej nauki, cotygodniowych ćwiczeń warsztatowych, które robią „moi operatorzy”, poznawanie „abecadła” i uczenie się „kaligrafii” to inne zagadnienie, którego tutaj nie będę omawiał.

Czym wobec tego jest film dokumentalny w roku 2015, gdy piszę te słowa? Na czym polega uczenie jego realizacji? Trzy lata temu PWSFTviT wydała Przewodnik dokumentalisty Grażyny Kędzielawskiej, zaopatrzony w podtytuł Podstawy warsztatu. Skrypt. Przewodnik zaopatrzony jest w osiem płyt DVD, na których znajdują się liczne przykłady ilustrujące wszystkie omawiane zagadnienia. Łapczywa lektura w pierwszej chwili mnie zachwyciła. Jednak z czasem pojawiły się gorzkie refleksje.

Aparat pojęciowy przynależy do minionego czasu, jest nieadekwatny do dzisiejszych technologii zdjęciowych i metod rejestracji dźwięku, do sposobu wykonywania zdjęć reporterskich i zdjęć filmo- 
wych w ogóle. Nawet określenia dotyczące prac literackich nie nadążają za nomenklaturą stosowaną przez PISF czy używaną w TVP.

Ale najistotniejsza wątpliwość dotyczy samego przedmiotu nauczania, dotyczy metod dydaktycznych służących nauczeniu studentów tworzenia filmów dokumentalnych. Grażyna Kędzielawska „od zawsze” uczy na pierwszym roku wydziału reżyserii, co ma dla studentów PWSFTviT zasadnicze znaczenie, gdyż formuje ich poglądy, ich aparat pojęciowy i podstawy warsztatu. W skrypcie zaś w żadnym „wprowadzeniu do ćwiczeń", w żadnym omówieniu wykładów prowadzonych na tym bazowym poziomie nie pojawiają się takie pojęcia, jak „temat” i „pomysł”, jak „opowiadanie” i „struktura” - jako problemy pierwszoplanowe. Film jest sztuką narracyjną i bez zdefiniowania tych pojęć jeszcze przed zdjęciami nie warto nawet wyciągać kamery z torby. Tu właśnie zrodził się mój sprzeciw. Czy można w roku 2015 rozmawiać ze studentami o filmie dokumentalnym, nie zaczynając od razu od tego, co najważniejsze - od uniwersalności i uogólnienia, jakie z filmu ma wyniknąć, od szukania metafory, którą niesie opowiadana historia i od zastanowienia się, czy opowiadanie będzie ciekawe?

I dotyczy to każdego gatunku filmu, każdej formy i każdej długości.

A wszystkie te sprawy ogniskują się w „temacie”. Sposoby, metody, chwyty warte są funta kłaków, jeśli nie służą do opowiedzenia ciekawej historii. I od tego kanonu: temat i ciekawa historia, należy zaczynać... i tym kończyć nauczanie filmu dokumentalnego. Pomiędzy początkiem i końcem jest ogromny obszar wiedzy o historii, o warsztacie, który świetnie rozłożyła na czynniki składowe Grażyna Kędzielawska w swoim Przewodniku dokumentalisty. Należy jednak pamiętać, że studenta „formatuje” pierwszy kontakt, pierwsze wysłuchane wykłady o tworzeniu filmów dokumentalnych. Albo zacznie on pracę nad swoim filmem od myślenia o temacie i przekazie, albo od myślenia o metodzie i formie. I to się stanie jego „pierwszym wyborem” w przyszłości. Moim zdaniem, studentów należy na początku drogi konfrontować z problemami podstawowymi: tematem filmu, jego przesłaniem, rangą opowiadanej historii. Forma jest tylko „opakowaniem”.

Nie stawiam sobie za cel pisania naukowej recenzji z Przewodnika dokumentalisty. Jednak rezygnując z wyszczególnienia i omówienia rzeczy - moim zdaniem - kontrowersyjnych, podam jeden przykład z piątego rozdziału, część: Zdjęcia. Oto cytat:

Istotna współpraca z dźwiękowcem:

- dokładne przygotowanie (omówienie) scen 100\%.

- ustalenie rodzajów efektów.

- omówienie charakteru offu i warunków jego nagrania.

- zebranie materiału dźwiękowego poza zdjęciami: tła, charakterystyczne efekty[1].

[1] G. Kędzielawska, Przewodnik dokumentalisty.

Podstawy warsztatu. Skrypt, Wydawnictwo Biblioteki

PWSFTviT, Łódź 2012, s. 71. 
Odnośnie do pierwszego punktu - dzisiaj w dokumencie z racji jednoczesnego nagrywania obrazu i dźwięku na jednej kamerze, na jednym nośniku, na dwóch do ośmiu ścieżkach, wszystko jest nagrywane stuprocentowo. Omawianiu podlegać może liczba używanych mikrofonów i sposób ich rozmieszczania. Sceny rozmów czy wywiady można robić w sposób minimalistyczny w trybie reporterskim $\mathrm{z}$ jednym mikrofonem kierunkowym bądź dopełniać go jednym lub więcej mikroportami. Z racji powszechnego używania kamery jako rejestratora dźwięku rola dźwiękowca sprowadza się w praktyce do funkcji mikrofoniarza. Za zapis staje się odpowiedzialny operator obrazu.

Punkt drugi. Nie rozumiem, co autorka ma na myśli, pisząc o „ustaleniu rodzajów efektów”. Efekty mogą być synchroniczne bądź niesynchroniczne. Efekty, których źródłem są obiekty widoczne w kadrze, jeśli zostały źle nagrane (z racji odległości bądź przerwania rejestracji przez wyłączenie kamery), wymagają prawidłowego nagrania, na osobnym rejestratorze, bez angażowania kamery i operatora. W tym samym trybie należy nagrywać efekty niesynchroniczne wymyślone/ zamówione przez reżysera, a głównie jako wynik twórczej inicjatywy dźwiękowca.

Sugestia trzecia, dotycząca omówienia offu, trąci myszką, odwołuje się do metod używanych w filmie dokumentalnym do lat 70 . ubiegłego wieku, używanych z konieczności w naszej Szkole w filmach realizowanych na taśmie $35 \mathrm{~mm}$. Dziś, w dobie elektroniki, wskazywanie studentom drogi rejestracji wywiadu tylko $\mathrm{z}$ magnetofonem jest niewłaściwe. A wyjątki od takiej reguły to zupełnie inna bajka.

Wreszcie po czwarte: nagrywanie tel, atmosfer, charakterystycznych efektów to konieczność, którą studentom trzeba wbijać do głowy. Ale mówienie o tym należy zacząć od uzmysłowienia konieczności posiadania niezależnego rejestratora dźwięku. I co tu mówić, w niskobudżetowych produkcjach dokumentalnych (szkolnych) musi o tym myśleć reżyser.

Tak więc moje wątpliwości związane $\mathrm{z}$ formułowaniem komunikatu do studenta polegają na tym, że jego geneza winna się brać z dnia dzisiejszego, a nie wczorajszego.

Film dokumentalny jaki jest?
Dziesięciominutowa kronika filmowa zniknęła $\mathrm{z}$ sal kinowych na świecie w latach 70. XX wieku. W Polsce dotrwała w kinach do połowy lat 9o. Wcześniej taki sam los spotkał „dodatek” - film animowany, oświatowy, dokumentalny, który emitowany był między kroniką a seansem głównym. Funkcje informacyjne, publicystyczne, a przede wszystkim rozrywkowe przejęła telewizja. A dla programu telewizyjnego optymalną „cegiełką” jest niecałe pół godziny albo niecała godzina. Zaczęliśmy robić długie dokumenty i poszło... Dzisiaj wielu z nas stara się robić filmy 90-minutowe i walczy o dystrybucję kinową.

Impresja, esej, portret dokumentalny, film przyrodniczy, film interwencyjny - bywają filmami długimi. Ale takie filmy, żeby przyciągnąć widza do kina, zachęcić go do zapłacenia za bilet, muszą być 
o czymś ciekawym, czyli mieć fascynujący „temat” lub „bohatera” i prezentować wciągającą historię opowiedzianą - najlepiej - w myśl zasad dramaturgii filmu fabularnego skodyfikowanych w dziesiątkach poradników scenariopisarstwa. Moim zdaniem to jest pierwsza litera elementarza filmowca dokumentalisty A.D. 2015.

Funkcje relacji dokumentalnej, kroniki, felietonu, reportażu, publicystyki przejęła nieodwracalnie telewizja, szczególnie przekaz na żywo, niemający nic wspólnego $z$ dramaturgią filmową. Pamiętam nasz zachwyt w latach 7o. kinowymi filmami z igrzysk olimpijskich: letnich i zimowych. Dzisiaj telewizyjny sposób pokazywania wydarzeń sportowych nie ma sobie równych, choć w inny, nienarracyjny, sposób. Dokumentalistyczna próba pokazania udziału polskiej reprezentacji piłkarskiej w Euro 2012, jaką podjął Marcin Koszałka w filmie Będziesz legenda człowieku (2012), gdy dodatkowo dramaturgia życia nie pomogła reżyserowi, dobitnie świadczy, że takie pomysły nie mają sensu.

Pomarańczową rewolucję w Kijowie oglądaliśmy na ekranach telewizorów pokazywaną przez polskie stacje telewizyjne, zarówno publiczne, jak i prywatne. Dlatego film zrealizowany przez Mirosława Dembińskiego Krasnoludki jadą na Ukrainę (2005) nie mógł zdobyć szerszej widowni kinowej. Podjęta przez reżysera próba wprowadzenia dramaturgii filmu drogi przy okazji opowiadania o podróży grupy młodzieży z Polski do Kijowa była słabą lokomotywą, nie budowała dramatu ani emocji.

Nie od rzeczy będzie wspomnieć film Robotnicy ' 80 . Toż to czystej wody relacja dokumentalna, po prostu zapis wydarzenia. Tylko że w Stoczni Gdańskiej im. Lenina w czasie sierpniowego strajku 1980 roku nie było państwowej telewizji ani radia. Wydarzenie, które wstrząsnęło Polską Ludową, stało się natychmiast mitem. Dlatego film/relację obejrzało w kinach kilka milionów ludzi. A potem był stan wojenny. Ten film oglądany dzisiaj jest śmiertelnie nudny, jednocześnie jednak fascynujący.

Każdy film dokumentalny funkcjonuje w swoim czasie, ma swój kontekst społeczny, polityczny i historyczny. Robiąc filmy dokumentalne dzisiaj, należy podejmować tematy ważne dzisiaj i opowiadać o nich ciekawie. To wezwanie do budowania interesujących historii ma dwa aspekty. Z jednej strony jest „fabularna” struktura dramaturgiczna, z drugiej zaś - atrakcyjna forma obrazu. Środki techniczne, postprodukcja, potrafią zrelatywizować wszystko. Co jest prawdą w obrazie, a co udawaniem, nie sposób rozróżnić. Materiały archiwalne płynnie przechodzą w zdjęcia inscenizowane, ikonografia miksuje się z rysunkiem. Nie potrafimy ocenić, czy oglądamy rekonstrukcję wydarzenia, czy zapis dokumentalny. To, czy obraz jest czarno-biały, czy barwny, o niczym nie świadczy. Ruch w obrazie odkształcamy w każdą stronę. Poczucie autentyzmu niebezpiecznie się zaciera, nawet fachowiec ma trudności z określeniem, gdzie się kończy fakt i dokument, a gdzie zaczyna autorska wariacja na temat...

Sławomir Idziak w moim filmie o nim $\left(\right.$ Idziak $\left.w_{3} D, 2011\right)$ narzeka na film fabularny dzisiejszej doby: „W tej chwili świat reklamy, 
czyli świat kompletnie skłamany, i świat kina fabularnego - stały się jakąś jednością". To samo można powiedzieć o filmie fabularnym i dokumentalnym - ich konwergencja bywa pełna, różnią się jedynie budżetami. W Szkole uprawiamy „klasyczny” film dokumentalny, w pełni zdjęciowy. Szczególnie na wydziale operatorskim, gdzie przecież chodzi o samodzielne wykonywanie zdjęć. Ale jak długo?

Przyznam się do rozterek, jakie miałem niedawno, realizując swój film dokumentalny. Postanowiłem stworzyć od zera historyczne wnętrze w naturalnym obiekcie; scenografia, rekwizyty, wynajmy, transport, ludzie, oświetlenie, jazda... Po to, żeby je obfotografować ze wszystkich stron. Normalny poziom kłopotów. I jednocześnie znalazłem w Internecie demo firmy komputerowej oferującej „silnik” do stworzenia animowanego wnętrza (za psie pieniądze), które można wyposażyć w dowolne meble i rekwizyty. Efekt ekranowy świetny, aż za dobry... Autentyzm rekonstruowanego obiektu i wynikająca z niego szlachetność dokumentu kontra komputerowa perfekcja. Do dziś nie wiem, czy postąpiłem słusznie.

Jaki jest film dokumentalny dzisiaj, w największej mierze zależy od tego, kto finansuje produkcję. Mam na myśli makro skalę tego zjawiska. Gdy piszę te słowa, właśnie pojawiło się w Internecie kolejne wezwanie najpoważniejszego gracza na filmowym rynku europejskim, funduszu wspierającego twórczość filmową „Kreatywna Europa. Media - Doc Lab Poland”. W tym wypadku jest to zaproszenie do zgłaszania swoich projektów do programu konsultacyjno-pitchingowego dla profesjonalnych twórców filmów dokumentalnych. Ważny jest tu termin „pitching” - to instytucja, w której aplikanci mogą mieć nadzieję na zdobycie na swój film europejskich pieniędzy. To wszystko gwoli wyjaśnienia. Bo ważna dla mnie jest zakreślona przez europejskich menedżerów od kultury tematyka, którą chcą wspierać. Oczekują twórców, którzy przyjdą z projektami społecznymi, historycznymi, edukacyjnymi, muzycznymi i sportowymi. Oczekują projektów charakteryzujących się autorskim i kreacyjnym podejściem. Co przez to rozumieją - czy tylko autorski punkt widzenia i autorską interpretację rzeczywistości? A na zakończenie stwierdzają enigmatycznie i lakonicznie, że projekty muszą mieć potencjał międzynarodowy. Można by każdy z tych punktów rozwinąć. Dziwi mnie w tej wyliczance obecność takich gatunków, jak film sportowy i historyczny. Ale lepiej pomyśleć, na jakie propozycje nie czekają.

Nie czekają na filmy obserwacyjne, kontemplacyjne, eksperymentalne, artystyczne czy w typie cinéma-vérité. Nie czekają na filmy montażowe, relacje, reportaże, publicystykę, impresję, esej, a nawet portret dokumentalny. Nie świadczy to bynajmniej, że takie filmy w Europie nie powstają i nie będą powstawać. Jak najbardziej. Oprócz filmów robionych dla telewizji jest potężny nurt filmów festiwalowych. Ale te dwie grupy filmów przenikają się w minimalnym stopniu. Zwycięzcy festiwali lądują w programie telewizyjnym na ogół koło północy. Przesadzam w wygłaszanych tu opiniach, chcąc wyostrzyć zarysowany obraz. 
Dywagując, jaki jest film dokumentalny dzisiaj, nie można przyjąć postawy strusia chowającego głowę w piasek i udawać, że nie ma reklamy, że w emisji w prywatnej/komercyjnej stacji telewizyjnej nasze dzieło nie będzie przerywane dwa lub trzy razy w ciągu godziny blokami reklamowymi trwającymi nawet 5-10 minut. To zabieg barbarzyński. Ale jeśli to wiemy, jeśli premierową emisję w Polsce na takim kanale ma obejrzeć najmarniej kilkadziesiąt tysięcy widzów, najczęściej kilkaset tysięcy, a nawet milion, to trzeba się nad tym zastanowić, trzeba te przerwy uwzględnić w strukturze dramaturgicznej, zbudować wyraźny podział na akty. Często nawet stosując przypomnienie treści poprzedniego aktu na początku aktu następnego. Trzeba to zrobić nawet tylko dla tej jednej emisji. Gdy nasz film ma istnieć także jako dzieło scalone, pokazywane bez reklam, to trzeba zrobić drugą wersję dla takiej formy prezentacji. Czasami widuję żałosne przykłady scalania, gdzie po prostu mechanicznie sklejono ze sobą akty, pozostawiając sceny przypominające. Bywa, że wówczas nawet wytrawny kinoman - jakim jest na przykład moja żona - gubi się i trzeba mu tłumaczyć pojawianie się bezsensownych powtórek akcji. To chleb codzienny filmu dokumentalnego w telewizjach komercyjnych i studenci muszą, moim zdaniem, przetrawić to intelektualnie, przerobić praktycznie.

Dla kogo robimy dzisiaj filmy dokumentalne? Odpowiedź, że robimy je dla każdego, jest półprawdą. Dla każdego w tym sensie, że dla kobiet i mężczyzn, dla dorosłych i młodzieży, dla widzów w Polsce, Europie i na świecie. Druga część prawdy polega na tym, że robimy je dla specyficznego widza - takiego, który poszukuje filmu dokumentalnego, który dokona aktu wyboru z przebogatej oferty setek kanałów ogólnych i tematycznych. Albo kupi bilet do kina. Więc robienie „czystej sztuki”, która sama się wybroni, podbije serca redaktorów programujących, jest mrzonką - ponieważ oni szukają unikatowej historii, frapująco opowiedzianej. Czekają na wielkie tematy. W pierwszej kolejności liczy się „co”, albowiem ,jak” film jest zrobiony w obliczu rangi tematu staje się mało istotne. Oczywiście w Szkole to, „jak” film jest zrobiony, musi mieć znaczenie, bo w Szkole uczymy także zawodu, czyli rzemiosła, a nie tylko wychowujemy artystów. Od dobrego rzemiosła do sztuki prowadzi mały krok.

Środki techniczne (w znaczeniu: sprzęt zdjęciowy) determinują metody tworzenia filmów. Ciężka, nieporęczna kamera filmowa na statywie zmuszała do dyscypliny w pracy, zmuszała do montażowego myślenia na planie. Elektronika pozwoliła zrzucić ostatecznie ograniczenia w ilości rejestrowanego materiału i mobilności kamery. Każde z tych ograniczeń tak jak i każda ze swobód ma swoje silne i słabe strony, może nieść pożądane i niepożądane skutki. Kamera na statywie albo kamera w ręku jest środkiem wyrazu, determinuje punkt widzenia rozumiany jako perspektywa, $z$ której film jest opowiadany. To nie jest ustalenie techniczne pomiędzy operatorem i reżyserem - to jest najważniejsza decyzja twórcza. A rozmowy o charakterze oświetlenia w filmie dokumentalnym straciły dzisiaj rację bytu, ponieważ 99 proc. 
zdjęć wykonuje się w warunkach zastanych. Przestaliśmy kreować światłem, adaptujemy się do... albo korygujemy to, co nam przynosi życie. I zawsze mamy jakieś wybory, które budują lepszą albo gorszą estetykę obrazu.

Umiejętność posługiwania się rejestratorami audiowizualnymi nabywają dzisiaj ośmo-, dziesięciolatki. Wówczas otrzymują swój pierwszy smartfon albo aparat. Zachód jest przed nami o co najmniej cztery dekady, gdyż tam od razu, gdy pojawił się amatorski zapis ruchomego obrazu (VHS), narzędzia te weszły do szkół, stały się głównymi instrumentami nauczania takich przedmiotów, jak sztuka czy media. Natomiast w polskich szkołach do dziś nie ma tego typu zajęć. Tworzenie wypowiedzi audiowizualnej jeszcze nie stało się przedmiotem nauczania. Pojawiła się wprawdzie Filmoteka Szkolna oczywiście to dobrze, ale czy o to chodzi, gdy najważniejszym celem nauczania winno być rozbudzanie umiejętności twórczych, a nie pasywnego odbioru czy konsumowania dóbr kultury? Jest zasadnicza różnica między odbiorem sztuki a tworzeniem. Steven Spielberg jako chłopiec dostał od swoich rodziców pierwszą kamerę i patrzcie państwo, co z tego wyszło...

Dzieci ze sztuką narracyjną zapoznają się dziś między innymi poprzez gry komputerowe, których cechą zasadniczą jest interaktywność. To narracje giętkie, otwarte, wariantywne. Bywali filmowcy, których zafascynowały te możliwości. Tylko mówiąc szczerze, pozostawienie widzowi wyboru zakończenia filmu czy wyboru, z czyjej perspektywy patrzenia podążamy za opowiadaną historią, jest bez sensu, jest antytezą sztuki filmowej. To reżyser z montażystą tworzą jedyną i optymalną strukturę filmu. Wariantywność i interaktywność są cechami gry komputerowej - i niech tak zostanie. Czy współczesna gra może być wyższą formą opowiadania filmowej historii, nie mnie sądzić.

Mogę sobie utyskiwać, ale na uniwersytety przychodzą dzisiaj młodzi ludzie lepiej przygotowani (?), na pewno inaczej przygotowani do studiowania swoich dziedzin. Są za pan brat z komputerami, grali w dziesiątki gier, robili filmiki, korzystając ze specjalistycznych programów. Dlatego wydaje mi się, że realizując cele nauczania w Szkole, trzeba zaczynać od wyraźnego opisania celu głównego, najdalszego - dzieła filmowego jako produktu ekranowego, a dopiero później ukazywać i porządkować cele pośrednie. Chciałem napisać: rugować nawyki brane $\mathrm{z}$ gier komputerowych. I tu się uszczypnąłem w rękę, czy aby na pewno? Może zrodziło się już coś innego, wychodzącego poza prawidła Arystotelesa, co niesie jakąś wartość, o której ja jeszcze nic nie wiem?

Film dokumentalny jest rodzajem filmu, w którym zawsze będzie dominować obraz rejestrujący rzeczywistość. Film fabularny $\mathrm{w}$ coraz większej mierze jest produktem wygenerowanym w komputerze. Oczywiście w dokumencie zdarzają się bardzo ciekawe przełamania tej tendencji, jak na przykład Walc z Baszirem (2008) Arie- 
go Folmana, który - choć jest w całości animowany - bez wątpienia pozostaje filmem dokumentalnym. Ale to przedstawiciel niewielkiej tylko grupy filmów. To oryginalny pomysł. Film dokumentalny ma za tworzywo rzeczywistość przed obiektywem i dlatego kapitalne znaczenie ma sposób jej fotografowania. I z tego punktu widzenia, z punktu widzenia sztuki operatorskiej, są tylko dwa sposoby jej fotografowania: sposób obiektywny, czyli zdystansowany, i sposób subiektywny, czyli uczestniczący.

Ten pierwszy sposób, obiektywny, zakłada tworzenie obrazów do montażu. Mechanizm napędzający pracę operatora tkwi w głowie to nieustanne konfrontowanie się z pytaniem, jak należy pokazywać dany problem, żeby dało się o nim filmowo opowiedzieć. Czekać, aby zaobserwować i uchwycić to, co ważne, a następnie jak zmieniać pozycję kamery, wielkość planu, jaki wprowadzać ruch kamery - żeby dało się to ze sobą zmontować, żeby można było zbudować scenę. I cały czas czekać na ważny moment, na znaczące słowo.

Drugi sposób, subiektywny, jest odwrotnością tego, co wyżej. To rejestracja uczestnicząca - kamerą, która jest w środku zdarzenia, obok bohatera - kamerą, która się przemieszcza, jest obecna, ale niewidoczna dla uczestników zdarzenia, jest przysłowiową „muchą na ścianie”. Fly on the wall - to termin, który zrodził się i został opisany w latach 60 . ubiegłego stulecia. Mechanizm napędzający pracę operatora zamknięty jest w uszach i oczach, cała uwaga skierowana na rozpoznawanie tego, co się wydarzy, aby właściwie zwrócić kamerę, podejść, zarejestrować to, co w danej chwili się dzieje i jest ważne. W praktyce filmowej pojęcie subiektywnego patrzenia ma dość nieostre granice. Kamera może stać się oczami protagonisty, w każdym razie - postaci ekranowej, ale może też stać się reprezentantem reżysera, a za jego pośrednictwem widza, może pozwolić widzowi na bardziej bezpośrednie uczestniczenie w akcji, na wejście w ekran. W dokumencie to bardzo sugestywny środek wyrazu, to bardzo mocny chwyt realizatorski. Oczywiście tak zbierany materiał do filmu owocuje godzinami nagrań. Daje szansę na uchwycenie wyjątkowych sytuacji. Ale zawsze wymaga kondensacji, wyciśnięcia jak cytryna, wymaga montażu. Tak więc przy tym kierowanym zmysłami filmowaniu operatorowi musi co pewien czas włączać się czerwone światełko ostrzegawcze w głowie. Ten materiał, koniec końców, najczęściej będzie także montowany...

Czy Uniwersytet jest w kryzysie? Tak - przeczytałem kiedyś $\mathrm{w}$ wywiadzie $\mathrm{z}$ byłym rektorem Uniwersytetu Warszawskiego. I to jest sytuacja prawidłowa, dodał, kiedy środowisko nauczycieli akademickich jakiejś uczelni dostrzega swój kryzysowy stan, to jest bardzo dobrym objawem, bo świadczy o autorefleksji, sprzyja otwieraniu furtek dla młodych ludzi - dla umiejętności, technologii, poglądów artystycznych, które ze sobą niosą. 